\title{
Metallothionein 3 attenuated the apoptosis of neurons in the CA1 region of the hippocampus in the senescence- accelerated mouse/PRONE8 (SAMP8)
}

\author{
Feiyu Ma', Hu Wang ${ }^{2}$, Bin Chen², Feng Wang ${ }^{3}$, Haixiong X ${ }^{4}$
}

\begin{abstract}
Objective: Metallothionein 3 (MT-3) has been shown to protect against apoptotic neuronal death in the brains of patients with Alzheimer's disease. Zinc is a potent inhibitor of caspase- 3 and its deficiency was found to promote apoptosis. Here, we measured the zinc and copper content in the brains of senescence-accelerated mouse/PRONE8 (SAMP8) and sought to investigate the effect of MT-3 on the apoptosis of neurons in the hippocampal CA1 region of these mice. Method: The zinc and copper content in the brain samples of SAMP8 and normal control SAMR1 mice were determined using an atomic absorption spectrophotometer. The mice were administered intraperitoneally for four weeks with MT-3 or MT1 and thereafter apoptosis was measured using the TUNEL method and the expression of anti-apoptotic protein $\mathrm{Bcl}-2$ and proapoptotic protein Bax was examined by immunohistochemistry. Results: Compared with that in SMAR1 mice, the content of zinc in the brains of SAMP8 mice was significantly reduced $(P<0.05)$. Moreover, significant levels of apoptosis of neurons were observed in the hippocampus of SAMP8 mice, which, compared with those in SMAR1 mice, also showed significantly lower levels of $\mathrm{Bcl}-2$ and higher levels of $\mathrm{Bax}(\mathrm{P}<0.05)$. MT-3 increased zinc concentration in the hippocampus of SAMP8 mice and also significantly decreased apoptosis in these neurons dose-dependently and increased the levels of Bcl-2 and decreased the levels of Bax. Conclusion: MT-3 could attenuate apoptotic neuron death in the hippocampus of SAMP8, suggesting that the protein may lessen the development of neurodegeneration.
\end{abstract}

Key words: metallothionein 3 (MT-3), SAMP8, neurodegeneration, apoptosis.

Metalotioneina 3 atenuou a apoptose dos neurônios da região CA1 do hipocampo em camundongos PRONE8 com envelhecimento acelerado (SAMP8)

\section{RESUMO}

Objetivo: Metalotioneína 3 (MT-3) tem mostrado proteção contra a apoptose neuronal em cérebros de pacientes com doença de Alzheimer. Zinco é um potente inibidor da caspase-3, e sua deficiência pode promover a apoptose. No presente trabalho, foram dosados os níveis de zinco e cobre nos cérebros de camundongos PRONE8 com envelhecimento acelerado (SAMP8), visando investigar o efeito da MT-3 na apoptse dos neurônios da região hipocampal CA1 destes camundongos. Método: Os níveis de zinco e cobre em amostras cerebrais de camundongos SAMP8 e de controles normais SAMR1

\section{Correspondence}

Haixiong Xu

Department of Orthopedics

Department of Neurosurgery

Shantou Central Hospital affiliated with

Sun Yat-sen University

Shantou, Guangdong 515041, China

E-mail: wang_jierui@yahoo.com.cn

Received 20 March 2010

Received in final form 11 June 2010

Accepted 18 June 2010 foram determinados por absorção atômica em espectrofotometria. Foram administradas MT-3 ou MT-1 intraperitoneais durante quatro semanas, sendo em seguida avaliada a apoptose pelo método TUNEL, enquanto a expressão da proteína anti-apoptótica Bcl2 e a proteína pró-apoptótica Bax foram avaliadas por imunohistoquímica. Resultados: Em comparação aos camundongos SMAR1, o nível de zinco nas amostras cerebrais dos

'Department of Neurology, Shantou Central Hospital affiliated with Sun Yat-sen University, Shantou, Guangdong 515041, China; ${ }^{2}$ Department of Orthopedics, First Affiliated Hospital, Shantou University Medical College, Shantou, Guangdong 515041, China; ${ }^{3}$ Department of Neurology, Sun Yat-sen Hospital, Xiamen University, Xiamen, Fujian 361004, China; ${ }^{4}$ Department of Neurosurgery, Shantou Central Hospital affiliated with Sun Yat-sen University, Shantou, Guangdong 515041, China. 
camundongos SAMP8 estava significativamente diminuído $(P<0.05)$. Além disto, níveis significativos de apoptose foram observados no hipocampo dos camundongos SAMP8, o que, em comparação com os níveis em camundongos SMAR1, também mostrava níveis significativamente mais baixos de $\mathrm{Bcl}-2$ e níveis mais altos de $\mathrm{Bax}(\mathrm{P}<0.05)$. MT-3 aumentou a concentração de zinco no hipocampo dos camundongos SAMP8, além de diminuir significativamente a apoptose destes neurônios, de uma forma dose-dependente, ao mesmo tempo que aumentou níveis de Bcl-2 e diminuiu níveis de Bax. Conclusão: MT-3 pode atenuar a morte neuronal apoptótica no hipocampo de SAMP8, o que sugere que esta proteína possa diminuir a neurodegeneração.

Palavras-chave: metalotioneína 3 (MT-3), SAMP8, neurodegeneração, apoptose.

Alzheimer's disease (AD) is a neurodegenerative disease and is characterized by the loss of neurons in the brain, especially in the CA1 region of the hippocampus. The clinical hallmarks of $\mathrm{AD}$ are progressive impairment in memory, judgment, and decision making. Apoptosis has been shown to be an important and major mechanism of neuronal death in AD. Autopsy of AD patients has revealed increased expression of Bax, a pro-apoptotic protein that regulates apoptotic signal transduction, and massive apoptosis of neurons in the brain ${ }^{1}$. Metallothioneins (MTs) constitute a family of proteins characterized by a high heavy metal content [ $\mathrm{Zn}(\mathrm{II})$ and $\mathrm{Cu}(\mathrm{I})]$ and also by an unusual abundance of cysteine residues. Mammalian metallothioneins are comprised of four major isoforms designated MT-1 through MT-4. MT-1 and MT-2 are expressed in most tissues including the brain, whereas MT-3 (also called growth inhibitory factor) and MT-4 are expressed predominantly in the central nervous system and in keratinizing epithelia, respectively. Despite their biochemical characterization, the in vivo functions of metallothioneins remain elusive. MT-3 was first isolated in 1991 by Uchida et al. in the brains of patients with $\mathrm{AD}^{2}$. There have been reports of decreased MT-3 content in model of $\mathrm{AD}^{3}$. Because zinc is a cofactor for multiple enzymes, it plays a critical role in brain development and normal functioning of the brain. Zinc deficiency or overload can both cause neuronal injury. Metallothioneins can bind and release zinc, and MT-3 stores and releases metal elements such as zinc and copper and maintains homeostasis of these metals in the cell ${ }^{4}$. Recently, MT-3 was shown to exert neuroprotective effects against brain ischemia in mice ${ }^{5}$. MT-3 may also alleviate or protect against apoptotic neuronal death in the brains of patients with $\mathrm{AD}$.

Senescence-accelerated mouse/PRONE 8 (SAMP8) developed by Takeda et al. show age-related behavioral deterioration such as deficits in learning and memory and emotional disorders and have an average lifespan of 12.1 months $^{6}$. These mice have been widely used by investigators to explore the etiopathogenesis of accelerated senescence and neurodegenerative disorders while senes- cence-accelerated mouse/resistant 1 (SAMR1) are used as normal control mice. The unique characteristic of SAMP8 mice is that it has a low incidence of other phenotypic aging alterations when its deficits in learning and memory are developed. SAMP8 mice have been considered by many investigators as a useful model for age-dependent neurodegeneration and senescence ${ }^{7-11}$. Moreover, zinc is a potent inhibitor of caspase- $3^{12}$, a protein critical for apoptotic cell death. In addition, depletion of zinc by chelation has been shown to promote apoptosis in vitro ${ }^{13}$. MT-3 stores and releases zinc and maintains zinc homeostasis. We hypothesized that there could be changes in the zinc content in SAMP8 mice and MT-3 could alleviate apoptosis of the neurons in the hippocampus of these mice. However, there has been no previous study of whether neurons in the brain of SAMP8 mice underwent apoptotic cell death and whether MT-3 could alleviate apoptosis in these neurons. In AD and other neurodegenerative diseases, the hippocampus is one of the first regions of the brain to suffer damages. In the present study, we measured the zinc and copper content of the hippocampus and investigated the apoptosis of neurons in the CA1 region of the hippocampus of SAMP8 mice and the effect on apoptosis of MT-3.

\section{METHOD}

\section{Animal grouping and treatments}

Eight-month-old male SAMP8 mice with a body weight of 25 to $30 \mathrm{~g}$ and 8-month-old male SAMR1 mice with a body weight of 30 to $40 \mathrm{~g}$ were provided by the Experimental Animal Center of Tianjin Traditional Chinese Medical College, Tianjin, China. These animals were housed in environmentally controlled conditions $\left(22^{\circ} \mathrm{C}\right.$, a $12 \mathrm{~h}$ light/dark cycle with the light cycle from 6:00 to 18:00 and the dark cycle from 18:00 to 6:00) with ad libitum access to standard laboratory chow and water. The SAMP8 mice were randomized into six groups with 10 mice in each group: the normal saline control group, low, mid, or high MT-3 group, MT1 group, and dementia group. MT1 and MT-3 were kindly provided by the Protein Engineering Laboratory of Peking University, Beijing, 
China. For the low, mid, and high MT-3 group, MT-3 was administered intraperitoneally for four consecutive weeks daily at a dose of $1.5,3$ or $6 \mathrm{mg} / \mathrm{kg}$ body weight, respectively. For the MT1 group, MT1 was administered intraperitoneally for four consecutive weeks at a dose of $3 \mathrm{mg} /$ kg body weight. Additionally, SAMR1 mice $(\mathrm{n}=10)$ served as normal controls.

\section{Measurement of zinc and copper content in the hippocampus of mice}

The animals were sacrificed by cervical dislocation one day after discontinuation of MT1 or MT-3 treatment and the brains were rapidly removed and washed with cold normal saline. The hippocampus was isolated on an ice-cold plate and weighed. The brain samples were digested by nitric acid (HNO3) until they became transparently liquid and the zinc and copper content were determined using an atomic absorption spectrophotometer and the zinc content was read at $213.9 \mathrm{~nm}$ and the copper content was read at $324.8 \mathrm{~nm}$.

\section{Western blotting studies}

The hippocampus from the animals was isolated as described above and protein samples were prepared as previously described ${ }^{14}$. The protein content of the samples was determined using the Bradford method. Equal amount of proteins was loaded from each sample (25 $\mathrm{mg}$ ) and resolved by SDS-PAGE. The following antibodies were used for immunoblotting studies: anti-Bcl-2 antibody, anti-Bax antibody, and anti-actin antibody (Calbiochem, La Jolla, CA). Immunoblotting studies were carried out as previously described ${ }^{15}$. The integrated optical density (IOD) values were determined using an image analysis work station configured with Kontron KS 400 software. IOD values for Western blots are IOD experimental/IOD control. Results for Bcl-2 and Bax were expressed as a ratio of $\mathrm{Bcl}-2$ or $\mathrm{Bax}$ over $\beta$-actin.

\section{Preparation of tissue sections of the hippocampus of mice}

The animals were anesthetized with sodium pentobarbital $(100 \mathrm{mg} / \mathrm{kg})$ one day after discontinuation of MT1 or MT-3 treatment and were perfused transcardially with $0.01 \mathrm{M}$ phosphate buffered saline (PBS, $\mathrm{pH}$ 7.4) followed by $4 \%$ paraformaldehyde in $0.1 \mathrm{M}$ phosphate buffer $(\mathrm{pH}$ 7.4). The brains were removed and routinely dehydrated with gradient alcohol. After treatment with xylene, the brains were embedded in paraffin and were transversely sectioned from $3.2 \mathrm{~mm}$ anterior to the bregma to 6.8 $\mathrm{mm}$ posterior to the bregma into 4 to $5 \mu \mathrm{m}$-thick slices with a cryostat after cryoprotection with $30 \%$ sucrose in PBS. The tissue sections were stored for TUNNEL staining and immunohistochemical studies.
The study protocol was approved by the local Institution Review Board and all the animal experiments were performed according to the guidelines of Institutional Animal Care and Use Committee at the Shantou University Medical College, Shantou, Guangdong, China.

\section{TUNEL assays}

In-situ detection of apoptosis in the hippocampus by the TUNEL method was carried out using a commercial kit as instructed by the manufacturer (Boster, Wuhan, China). Briefly, the paraffin-embedded sections were deparaffined and dehydrated and fixed in $4 \%$ paraformaldehyde. After digestion with proteinase $\mathrm{K}$ and fixation in $4 \%$ paraformaldehyde, the tissue sections were equilibrated for 5 to $10 \mathrm{~min}$ at room temperature and incubated with $\mathrm{TdT}$ reaction buffer in the dark for $60 \mathrm{~min}$. Thereafter, the sections were incubated with $2 \times$ SSC at room temperature for $15 \mathrm{~min}$ for termination of the reaction followed by rinse in $0.3 \% \mathrm{H}_{2} \mathrm{O}_{2}$. Streptavidin-HRP solution was subsequently added to the tissue sections. After wash in ultra-pure water, the sections were mounted on glass slide with VECTASHIELD Mounting Medium (Vector Labs). The nuclei of apoptotic cells were labeled brown under DAB staining. Under 400× magnifications, 20 visual fields were randomly selected to count the number of apoptotic cells and the total number of cells, respectively. The apoptosis index $(\mathrm{AI})=$ (number of apoptotic cells/number of total cells) $\times 100 \%$.

\section{Immunohistochemistry}

The paraffin-embedded sections were deparaffined and dehydrated followed by treatment with $1 \% \mathrm{H}_{2} \mathrm{O}_{2}$. Antigen retrieval was carried out using citrate buffer. The sections were then incubated with the following primary antibodies overnight at $4{ }^{\circ} \mathrm{C}$ : rabbit anti-mouse Bax polyclonal antibody or rabbit anti-mouse $\mathrm{Bcl}-2$ polyclonal antibody followed by incubation with biotinylated goat anti rabbit IgG. After treatment with streptavidin-HRP and staining with $\mathrm{DAB}$, the sections were stained with hematoxylin and mounted. Ten slices were obtained from mice in each group and each slice was photographed .

\section{Statistical analysis}

Statistical analysis was carried out using the SPSS 10.0 software (SPSS, Chicago, Illinois) and the data were expressed as mean \pm standard deviation $(\overline{\mathrm{x}} \pm \mathrm{SD})$. ANOVA was used for comparison of data among the three groups given different doses of MT-3. Student's t-test was used for comparison of data between the experimental groups and the control group. Chi-square test was used for comparing the apoptotic indexes among the groups. $\mathrm{P}<0.05$ was considered statistically significant. 


\section{RESULTS}

\section{MT-3 increased zinc concentration in} the hippocampus of SAMP8 mice

We examined the zinc and copper contents of the hippocampus of normal control SAMR1 mice and SAMP8 mice. We found that, compared with that of normal controls, the content of zinc in the hippocampus of SAMP8 mice was significantly reduced (Table 1$)(\mathrm{P}<0.05)$. Treatment of SAMP8 mice with MT-3 raised the zinc content of the hippocampus, and the greatest increase in zinc content was observed in SAMP8 mice treated with mid doses of MT-3. In addition, MT1 also increased the zinc concentration in the hippocampus of SAMP8 mice. However, no statistical difference was observed in the copper content of the hippocampus of SAMR1 and SAMP8 mice (Table 1).

\section{MT-3 reduced apoptosis of neurons in the CA1 region of the hippocampus in a dose- dependent manner in SAMP8 mice}

Zn deficiency has been shown to induce apoptosis in neuronal cells ${ }^{6}$ and we examined whether low zinc content in the hippocampus of SAMP8 mice was associated with apoptosis of neurons in the CA1 region and the effect of MT-3 on the apoptotic cell death of neurons in the hippocampus using the TUNEL method and found that
Table 1. Zinc and copper content in the hippocampus of mice $(\bar{x} \pm S D, \mu g / g)(n=10)$.

\begin{tabular}{lcc}
\hline Group & Zinc & Copper \\
\hline SAMR1 & $20.89 \pm 2.83$ & $2.72 \pm 0.57$ \\
SAMP8 & $13.76 \pm 1.48^{\mathrm{a}}$ & $3.95 \pm 0.74$ \\
NS & $12.75 \pm 1.31$ & $3.81 \pm 0.59$ \\
Low MT-3 & $17.43 \pm 2.08$ & $3.12 \pm 0.47$ \\
Mid MT-3 & $21.75 \pm 2.94^{\mathrm{bc}}$ & $2.99 \pm 0.84$ \\
High MT-3 & $16.16 \pm 3.86$ & $4.56 \pm 0.89$ \\
MT1 & $19.69 \pm 3.10$ & $3.43 \pm 0.90$
\end{tabular}

${ }^{a}$ Compared with normal controls, $\mathrm{P}<0.05$; ${ }^{\mathrm{b}} \mathrm{Compared}$ with low or high MT-3, $\mathrm{P}<0.05$; ${ }^{\mathrm{C}} \mathrm{C}$ mpared with NS controls, $\mathrm{P}<0.05$. NS, normal saline.

minimal apoptosis of neurons $(5.6 \pm 1.1 \%)$ was observed in the CA1 region of the hippocampus in normal control mice SAMR1 (Fig 1A). By contrast, we detected massive apoptosis of neurons in the hippocampus CA1 region $(38.8 \pm 3.1 \%)$ in the dementia group (Fig 1B). The difference in AI between SAMR1 and dementia group was statistically significant $(\mathrm{P}<0.01)$, suggesting that dementia was associated with neuronal apoptotic death. Additionally, administration of low, mid or high doses of MT-3 yielded an AI of $23.4 \pm 3.6 \%, 20.1 \pm 4.5 \%$, and $15.7 \pm 3.9 \%$, respectively, indicating that MT-3 caused a dose-dependent reduction in the apoptotic cell death, and the $\mathrm{AI}$ in
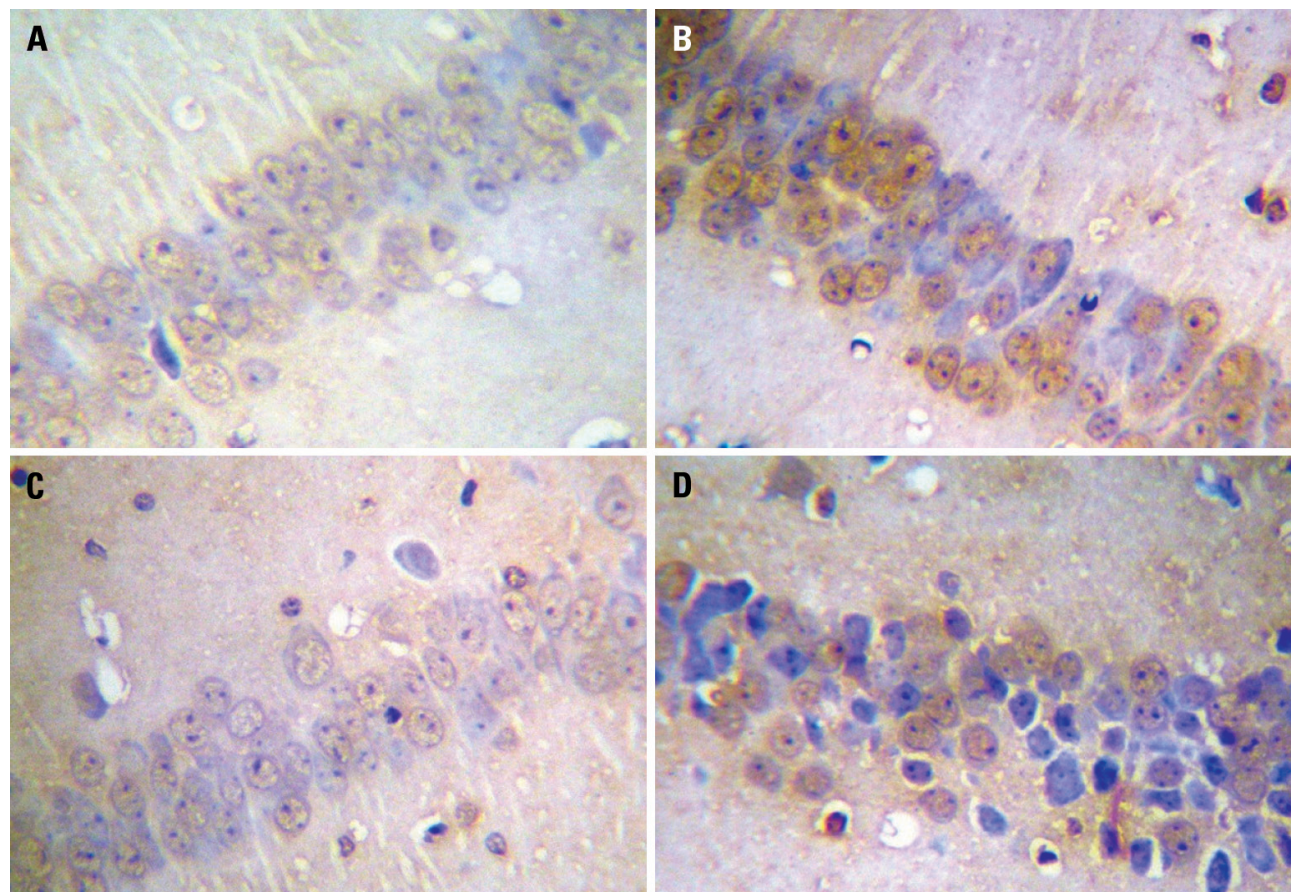

Fig 1. MT-3 attenuated apoptosis of neurons in the CA1 region in SAMP8 mice. Apoptosis was examined using the TUNEL method. [A] Minimal apoptosis was noted in the CA1 region of the hippocampus in normal control mice SAMR1. [B] Massive apoptosis was observed in the hippocampus CA1 region of SAMP8 mice. [C] High dose of MT-3 attenuated the apoptosis of neurons in the hippocampus of SAMP8 mice more effectively than MT1 [D]. $\times 400$. 
the low, mid, and high dose group was significantly lower than that of normal saline group $(\mathrm{P}<0.05)$. Furthermore, MT- 3 and MT1 at comparable doses showed similar rates of apoptosis with an AI of $20.1 \pm 4.5 \%$ and $21.6 \pm 3.8 \%$, respectively (Fig $1 \mathrm{C}$ and $1 \mathrm{D}$ ).

\section{MT-3 modulated dose-dependently the levels of $\mathrm{BCl}-2$ and $\mathrm{Bax}$ in the neurons in the CA1 region of the hippocampus in SAMP8 mice}

$\mathrm{Bcl}-2$ is an anti-apoptotic protein and inhibits apoptosis by stabilizing the mitochondrial membrane. We examined whether the effects of MT-3 on the apoptosis of neurons in the dementia mice were associated with changes in the levels of Bcl-2. Western blotting studies using anti-Bcl-2 antibody revealed that $\mathrm{Bcl}-2$ was expressed at significantly higher levels in the normal control SAMR1 mice $(\mathrm{IOD}=5.25 \pm 0.91)$ than those of SAMP8 mice $(\mathrm{IOD}=2.89 \pm 0.81)(\mathrm{P}<0.05)($ Fig $2 \mathrm{~A}$ and $2 \mathrm{~B})$ (Table 2). Furthermore, treatment with MT-3 caused a dose-dependent increase in Bcl-2 levels and the levels of $\mathrm{Bcl}-2$ in SAMP8 mice treated with high doses of MT-3 were significantly higher than those of the normal saline control SAMP8 mice $(\mathrm{P}<0.05)$ and were similar to those of the normal control SAMR1 mice (Table 2). Though the levels of Bcl-2 were higher in the SAMP8 mice treated with MT-3 than those treated with comparable doses of
Table 2. Bcl-2 and Bax expression (in integrated optical density, $\left.I O D ; \times 10^{6}\right)$ in the hippocampus of mice ( $n=10$ /group).

\begin{tabular}{lccc}
\hline Group & Bcl-2 & Bax & Bcl-2/Bax \\
\hline SAMR1 & $5.25 \pm 0.91$ & $9.43 \pm 2.66$ & 0.56 \\
SAMP8 & $2.89 \pm 0.81^{1}$ & $25.86 \pm 7.86^{1}$ & 0.11 \\
NS & $2.90 \pm 0.38$ & $26.31 \pm 5.82$ & 0.11 \\
Low MT-3 & $3.16 \pm 0.75$ & $24.21 \pm 4.75$ & 0.13 \\
Mid MT-3 & $4.67 \pm 0.99$ & $17.13 \pm 4.02^{3,4}$ & 0.27 \\
High MT-3 & $5.02 \pm 1.53^{3}$ & $15.96 \pm 4.63^{2,3}$ & 0.31 \\
MT1 & $3.81 \pm 1.17$ & $21.51 \pm 5.74$ & 0.18
\end{tabular}

${ }^{1}$ Compared with SAMR1, $\mathrm{P}<0.05 ;{ }^{2}$ Compared with low or mid MT-3 group, $\mathrm{P}<0.05 ;{ }^{3} \mathrm{Compared}$ with NS group, $\mathrm{P}<0.05 ;{ }^{4} \mathrm{C}$ mpared with MT1 group, $\mathrm{P}<0.05$. NS, normal saline.

MT1, no significant statistical difference was noted between the two groups (Table 2) (Fig 2C and 2D) ( $\mathrm{P}>0.05$ ). The findings suggest that MT-3 may attenuate apoptosis of neurons in the CA1 region of the hippocampus in the SAMP8 mice by upregulating Bcl-2 levels.

We further examined whether treatment of the SAMP8 mice affected the levels of Bax, which is an important pro-apoptotic protein and regulates the apoptotic signal transduction to the mitochondria. Our histochemical study using anti-Bax antibody showed that Bax was only weakly expressed in the normal control SAMR1
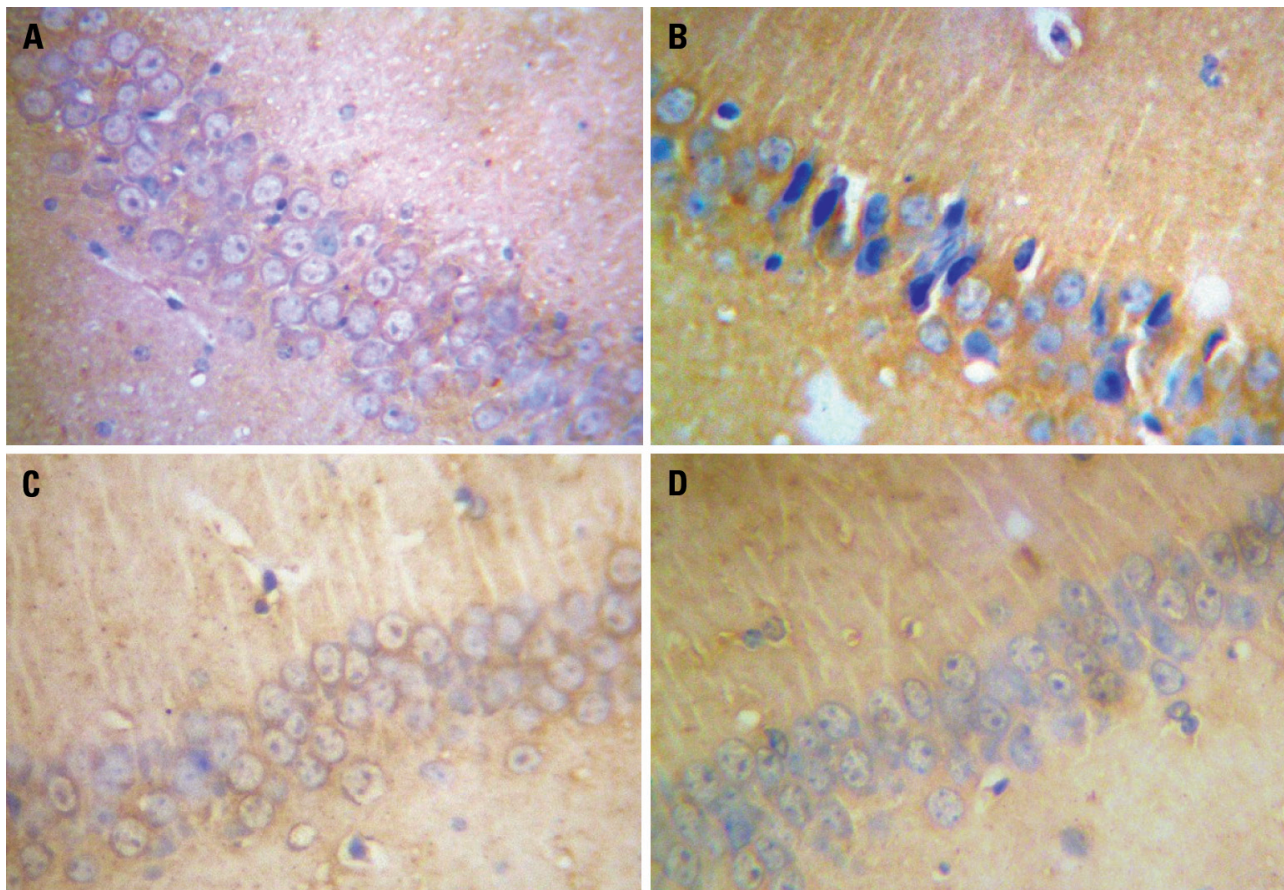

Fig 2. MT-3 upregulated $\mathrm{BCl}-2$ levels of neurons in the CA1 region of the hippocampus in the SAMP8 mice. Immunohistochemical study using anti-BCl-2 antibody showed a higher level of $\mathrm{BCl}-2$ expression in the normal control SAMR1 mice [A] than that of SAMP8 mice [B]. High dose of MT-3 increased the levels of $\mathrm{BCl}-2$ in SAMP8 mice [C]. MT1 also increased the expression of $\mathrm{BCl}-2$ in the CA1 region of the hippocampus of SAMP8 mice [D]. $\times 400$. 
mice and its levels were significantly lower than those of the dementia group (Table 2) (Fig 3A and 3B) $(\mathrm{P}<0.05)$, which showed high levels of Bax expression. Treatment of SAMP8 mice with various doses of MT-3 caused a dose-dependent reduction in Bax levels, and high doses of MT-3 induced a more significant reduction in Bax levels than mid or low doses of MT-3 (Table 2) $(\mathrm{P}<0.05)$. Furthermore, comparable doses of MT-3 more significantly decreased the levels of Bax than MT1 (Table 2) (Fig $3 \mathrm{C}$ and $3 \mathrm{D})(\mathrm{P}<0.05)$.

\section{DISCUSSION}

MT-3 is highly expressed in the brain and plays a critical role in the homeostasis of the essential metal ions copper and zinc. Zinc is an essential element for metallothioneins, and MT-3 can store and release zinc in the brain. We found that senescence and neurodegeneration in SAMP8 mice were associated with a reduced zinc content compared with SAMR1, suggesting a derangement in the homeostasis of the redox active metal. In addition, we found that MT-3 restored zinc level to that of healthy control SAMR1 mice. MT-3, as an important regulator of zinc homeostasis in the brain, is considered a buffer of highly fluctuating concentrations of zinc. Metallothioneins usually bind seven divalent metal ions ( $\mathrm{Zn}$ (II) or $\mathrm{Cd}(\mathrm{II}))$ and up to 12 monovalent copper ions through thiolate bonds ${ }^{16}$. MT-3 contains both $\mathrm{Zn}(\mathrm{II})$ and $\mathrm{Cu}(\mathrm{I})$ ions, i.e., $\mathrm{Cu} 4, \mathrm{Zn} 3-\mathrm{MT}-3^{17,18}$. Our finding that MT-3 increased zinc level in SAMP8 mice could be due to the release of zinc from MT-3 which buffers against fluctuating zinc levels in the body.

$\mathrm{Zn}$ (II) homeostasis in the brain is relevant to $\mathrm{AD}$ because $\mathrm{Zn}$ (II) released during neurotransmission may bind to A peptides, accelerating the assembly of A into oligomers, which have been shown to impair synaptic function ${ }^{19}$. Individuals with $\mathrm{AD}$ were found to experience a significant loss of ZnT3 mRNA expression in the cortical regions compared with controls ${ }^{20}$, suggesting that neuronal cells in particular have markedly reduced expression of ZnT3 mRNA. A consensus on the zinc content in the brains of SAMP8 mice has not yet been established ${ }^{21}$. SAMP8 mice have been a widely utilized model for studying neurodegeneration, which is a key feature of $\mathrm{AD}$. We found that the zinc content was markedly reduced in the brains of SAMP8 mice compared with SAMR1, suggesting a derangement in the homeostasis of the redox active metal. Metal chelation has been proposed as a possible therapeutic modality for $\mathrm{AD}$ to restore homeostasis of redox active metals such as zinc and copper ${ }^{22}$. MT-3, as an important regulator of zinc homeostasis in the brain, could alleviate derangement in zinc homeostasis. Our finding that
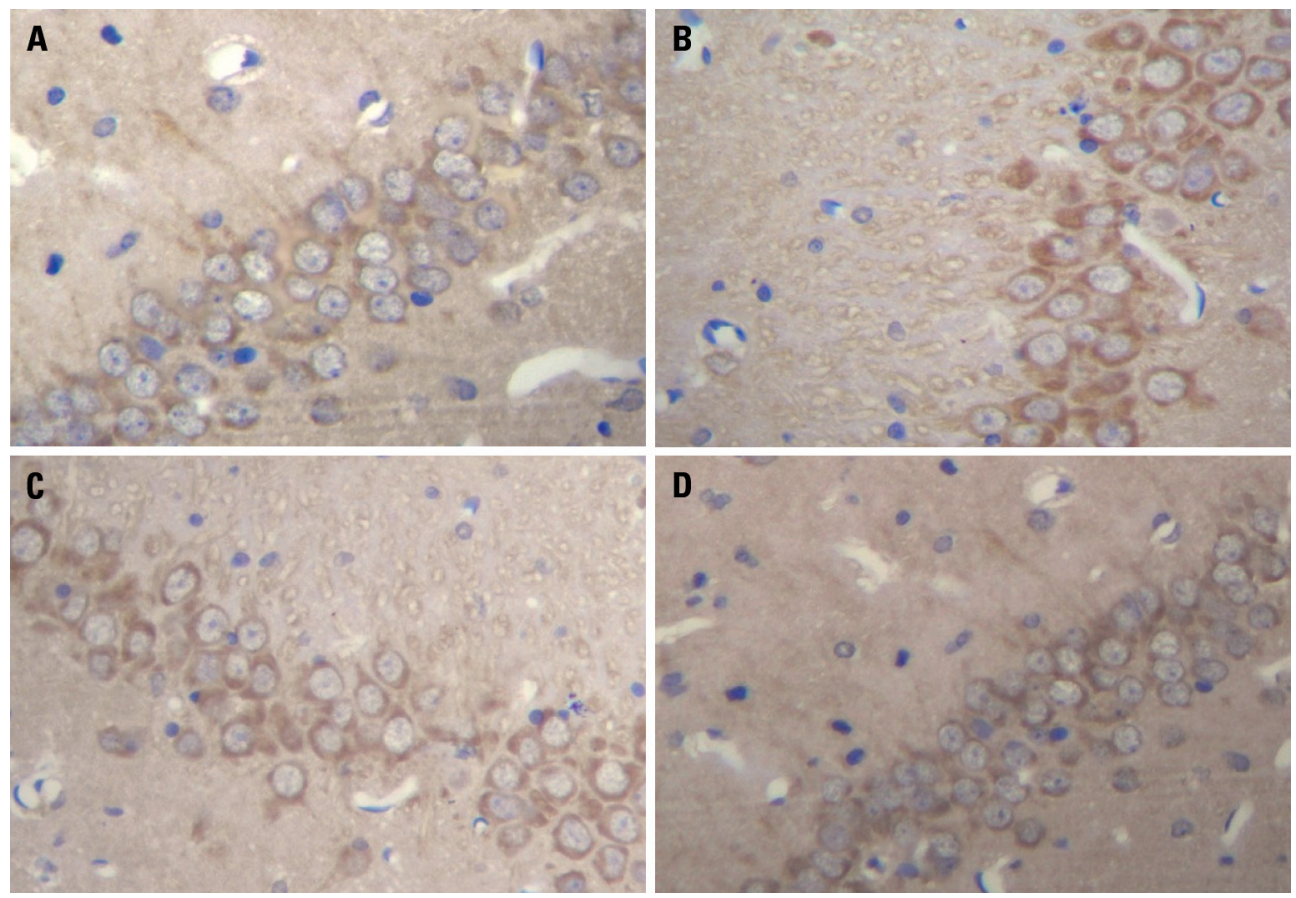

Fig 3. MT-3 reduced the levels of Bax in the CA1 region of the hippocampus in SAMP8 mice. Immunohistochemical study using anti-Bax antibody showed a weak expression of Bax in the normal control SAMR1 mice [A]. A noticeably higher level of Bax expression was found in SAMP8 mice [B]. High dose of MT-3 [C] reduced the levels of Bax expression in the CA1 region of the hippocampus in SAMP8 mice more effectively than MT1 [D]. 
MT-3 restored zinc level to that of the healthy control SAMR1 mice suggested that MT-3 could be of potential use for treating neurodegenerative diseases such as AD.

We found here that MT-3 could reduce apoptosis of neurons in the CA1 region of the hippocampus in a dosedependent manner in SAMP8 mice. This increased apoptosis of these neurons could be due to the ability of zinc to inhibit apoptosis. Zinc is a potent inhibitor of caspase- $3^{23}$, a protein critical for apoptotic cell death. In addition, depletion of zinc by chelation has been shown to promote apoptosis in $v i t r{ }^{13}$. We speculate that the ambient release of zinc from MT-3 could contribute to the MT-3-induced inhibition of apoptosis. This could account for the observation that apoptotic inhibition is dependent on MT-3 levels as more zinc would be liberated in cells containing more MT-3. Therefore, zinc bound to MT-3 may play an important role in the control of apoptosis, although further studies will be required to establish this as a critical factor for MT-3-mediated inhibition of apoptosis.

Smale et al. found that neurons in the hippocampus of patients with $\mathrm{AD}$ underwent massive apoptosis, which was 30 to 50 fold higher than in normal brains ${ }^{24,25}$. We also detected high levels of apoptosis in SAMP8 mice, which were significantly higher than those of normal SAMR1 mice, suggesting that accelerated senescence and neurodegeneration in SAMP8 mice was associated with massive neuronal apoptotic death. The Bcl-2 family are important regulators of cellular apoptosis and $\mathrm{Bcl}-2$ is one of the most active inhibitors of apoptosis and can inhibit apoptosis caused by many factors ${ }^{26}$. Highly expressed Bcl-2 prevents increased mitochondrial permeability induced by apoptotic stimuli us, thus inhibiting the onset of apoptosis. Bax is a pro-apoptotic protein that regulates apoptotic signal transduction to the mitochondria. $\mathrm{Bcl}-2$ and Bax are also important for controlling the apoptotic process in neurons. Our immunohistochemical analysis of the expression of $\mathrm{Bcl}-2$ and $\mathrm{Bax}$ in the $\mathrm{CA} 1$ region of the hippocampus suggested a predisposition to apoptotic death of neurons in SAMR1 mice. MT-3 could significantly attenuate apoptosis of neurons in the CA1 region of the hippocampus of SAMP8 mice. We further found that MT-3 could modulate the expression of Bcl2 and Bax in these neurons and noticeably increased the expression of Bcl-2 and decreased that of Bax, suggesting that MT-3 could influence the balance between apoptotic cell death and cellular survival of neurons.

$\mathrm{AD}$ disease is a devastating disease and poses a serious public health problem. Currently, there is lack of effective treatments for $\mathrm{AD}$ and it is imperative to find new effective pharmacotherapies. Our findings indicate that MT-3 may be neuroprotective against premature senescence and neurodegeneration by restoring homeostasis of redox active metals such as zinc and attenuate the apop- totic process in the brain. The pharmacotherapeutic role of MT-3 should be further explored.

\section{REFERENCES}

1. Pompl PN, Yemul S, Xiang, Ho L, et al. Caspase gene expression in the brain as a function of the clinical progression of Alzheimer disease. Arch Neurol 2003;60:369-376

2. Uchida Y, Takio K, Titani K, et al. The growth inhibitory factor that is deficient in the Alzheimer's disease brain is a 68 amino acid metallothioneinlike protein. Neuron 1991;7:337-347.

3. Martin BL, Tokheim AM, McCarthy PT, Doms BS, Davis AA, Armitage IM. Metallothionein-3 and neuronal nitric oxide synthase levels in brains from the Tg2576 mouse model of Alzheimer's disease. Mol Cell Biochem 2006; 283:129-137.

4. Tokuda E, Ono SI, Ishige $\mathrm{K}$, et al. Metallothionein proteins expression, copper and zinc concentrations, and lipid peroxidation level in a rodent model for amyotrophic lateral sclerosis. Toxicology 2007;229:33-41.

5. Koumura A, Hamanaka J, Shimazawa M, et al. Metallothionein-III knockout mice aggravates the neuronal damage after transient focal cerebral ischemia. Brain Res 2009;1292:148-154.

6. Takeda T. Senescence-accelerated mouse (SAM) with special references to neurodegeneration models, SAMP8 and SAMP10 mice. Neurochem Res 2009;34: 639-659.

7. Chiba Y, Shimada A, Kumagai N, et al. The senescence-accelerated mouse (SAM): a higher oxidative stress and age-dependent degenerative diseases model. Neurochem Res 2009;34:679-687.

8. Tomobe K, Nomura Y. Neurochemistry, neuropathology, and heredity in SAMP8: a mouse model of senescence. Neurochem Res 2009;34:660-669.

9. Zhang $\mathrm{Q}$, Ding $\mathrm{H}$, Li W, et al. Senescence accelerated mouse strain is sensitive to neurodegeneration induced by mild impairment of oxidative metabolism. Brain Res 2009;1264:111-118.

10. Banks WA, Morley JE, Klein JB, Butterfield DA. Quantitative proteomics analysis of specific protein expression and oxidative modification in aged senescence-accelerated-prone 8 mice brain. Neuroscience 2004;126: 915-926.

11. Poon HF, Joshi G, Sultana $R$, et al. Antisense directed at the Abeta region of APP decreases brain oxidative markers in aged senescence accelerated mice. Brain Res 2004;1018:86-96.

12. Perry DK, Smyth MJ, Stennicke HR, et al. Zinc is a potent inhibitor of the apoptotic protease, caspase-3. A novel target for zinc in the inhibition of apoptosis. J Biol Chem 1997;272: 18530-18533.

13. Chimienti F, Seve M, Richard S, Mathieu J, Favier A. Role of cellular zinc in programmed cell death: temporal relationship between zinc depletion, activation of caspases, and cleavage of Sp family transcription factors. Biochem Pharmacol 2001;62:51-62.

14. Stommel JM, Wahl GM. Accelerated MDM2 auto-degradation induced by DNA-damage kinases is required for p53 activation. Embo J 2004;23: 1547-1556.

15. Cui B, Johnson SP, Bullock N, Ali-Osman F, Bigner DD, Friedman HS. Bifunctional DNA alkylator 1,3-bis(2-chloroethyl)-1-nitrosourea activates the ATR-Chk1 pathway independently of the mismatch repair pathway. Mol Pharmacol 2009; 75:1356-1363.

16. Vasa'k M, Kagi JHR. Metallothionein. In: King RB (Ed.). Encyclopedia of inorganic chemistry. New York: John Wiley \& Sons Ltd. 1994: 2229-2241.

17. Bogumil R, Faller P, Pountney D L, Vasak M. Evidence for $\mathrm{Cu}(\mathrm{I})$ clusters and $\mathrm{Zn}(\mathrm{II})$ clusters in neuronal growth-inhibitory factor isolated from bovine brain. Eur J Biochem 1996;238: 698 -705.

18. Uchida $Y$, Takio K, Titani K, Ihara $Y$, Tomonaga $M$. The growth inhibitory factor that is deficient in the Alzheimer's disease brain is a 68 amino acid metallothionein-like protein. Neuron 1991;7: 337-347.

19. Lovell MA. A potential role for alterations of zinc and zinc transport proteins in the progression of Alzheimer's disease. J Alzheimers Dis 2009:16:471-483.

20. Beyer N, Coulson DT, Heggarty S, Ravid R, Irvine GB, Hellemans J. ZnT3 mRNA levels are reduced in Alzheimer's disease post-mortem brain. Mol Neurodegener 2009:4:53.

21. Adamo AM, Zago MP, Mackenzie GG, et al. The role of zinc in the modulation of neuronal proliferation and apoptosis. Neurotox Res 2010;17:1-14.

22. Cuajungco MP, Faget KY. Zinc takes the center stage: its paradoxical role in Alzheimer's disease. Brain Res Brain Res Rev 2003;41:44-56.

23. Perry DK, Smyth MJ, Stennicke HR. Zinc is a potent inhibitor of the apoptotic protease, caspase-3. A novel target for zinc in the inhibition of apoptosis. J Biol Chem 1997;272: 18530-18533

24. Cuajungco MP, Fagét KY, Huang $X$, et al. Metal chelation as a potential therapy for Alzheimer's disease. Ann N Y Acad Sci 2000;920:292-304.

25. Smale G, Nichols NR, Brady DR, Finch CE, Horton WE Jr. Evidence for apoptotic cell death in Alzheimer's disease. Exp Neurol 1995;133:225-230.

26. Stadelmann C, Deckwerth TL, Srinivasan A, et al. Activation of caspase-3 in single neurons and autophagic granules of granulovacuolar degeneration in Alzheimer's disease. Evidence for apoptotic cell death. Am J Pathol 1999:155:1459-1466. 